\title{
Do Stock Exchanges Make Differences on Macroeconomic Performance and Economic Growth in Sub-Saharan African (SSA) Countries?
}

\author{
Kassahun Wolde Assfaw ${ }^{1,}$ Professor G.S.Batra ${ }^{2}$ \\ School of Management Studies, Punjabi University, Patiala, India \\ ${ }^{1}$ PhD Scholar, School of Management studies, Punjabi University and Lecturer at Mizan-Tepi University, \\ Ethiopia, Department of Accounting \& Finance \\ ${ }^{2}$ Professor and PhD. supervisor, School of Management studies, Punjabi University \\ ${ }^{* *}$ This is part of the PhD Thesis titled: Establishment of a Viable Stock Market in Ethiopia: A study of \\ Macroeconomic and Institutional Factors
}

\begin{abstract}
The study examines whether there is significant difference on macroeconomic performance between SSA countries which have stock exchanges and countries which do not have after these countries are ranked on the basis of their macroeconomic performance composite index, computed using a multi-criteria decision making (TOPSIS) method and Shannon entropy to calculate the objective weight for each criterion. The study finds that there is meaningful difference on macroeconomic performance between the two groups of countries. However, the independent sample T-test tells that there is no significant difference on GDP growth between SSA countries, with stock exchanges and countries without stock exchanges for the years 1997-to-2013. A random effect regression result, that is found to be appropriate after Hausman test, shows the stock market development indicators positively impact GDP growth rate of 17 African countries that are members of African stock exchange Association for the years 2003-to-2014. While market capitalization as percentage of GDP is significant, turnover ratio is not significant. African countries need to be determined to develop their stock markets so that they can have significant impact on enhancing economic growth in a manner that significant difference on GDP growth is observed between countries with stock exchanges and without stock exchanges controlling for other variables.
\end{abstract}

Keywords: Composite index, Ideal solution, Multi-criteria, Normalization, Objective weight, TOPSIS,

\section{Introduction}

Stock markets are claimed to facilitate higher investment and the allocation of capital and indirectly the economic growth (Wamburu, K. K. \& Wainaina,G., 2014), [1] Bekaert and Harvey (1997) [2], (Carporale and et al, 2004)) [3]. They provide a way for growing companies to raise capital from external sources relatively easily compared to companies operating in countries where stock markets are absent and bank dominated. A number of studies have been conducted on the finance- economic growth nexus and prescribe establishment of stock market as quickly as possible as means of financing development projects and thereby speeding up the economic growth (Atje R., and Jovanovic B, 1989)[4]. The linkage between stock market development and economic growth is widely studied subject in finance and economics and it seems the view that stock market promotes economic growth is well accepted (K. Filer and et al, 1999)[5], Al-Qudah, (2014)[6], Ngare and et al (2014)[7], O. Olweny and Kimani, (2011)[8] ,Boubakari and Jin, (2010)[9] ,Levine, (1996)[10]

Economic growth, which each nation is striving to achieve, is one major component of nations' macroeconomic policy and establishment of stock exchanges are viewed as instruments enhancing growth thereby contributes positively towards macroeconomic performance. Generally, stock markets are considered as barometer of a given economy (Musonera and Safari, 2008) [11]. Macroeconomic policy is generally viewed as being committed to three goals: price stability, employment creation, and growth (Welsch, 2011)[12]. When the relative macroeconomic performance of countries is sought to be determined, it is needed to evaluate and rank the countries with respect to their macroeconomic performance. Since these goals are usually viewed as involving trade-offs, unless there is a composite index that takes all the goals in to consideration, it will be hardly possible to reasonably measure the performance of countries and rank them accordingly.In this study, effort has been made to rank Sub-Saharan African countries on the basis of their macroeconomic performance, measured using a macroeconomic performance composite index, computed using a Multi criteria decision making Technique for Order Preference by Similarity Ideal Solution (TOPSIS) method.

Following the ranking, an independent sample T-test has been done to see whether there is significant difference on the average growth rate of Sub-Saharan African (SSA) countries that have stock exchanges and 
those do not have for the years 1997-to-2013.The remaining section of this study is divided into nine parts. Section two discusses literature review. Importance of the study and statement of the problem are dealt in sections three and four respectively. Section five presents objectives of the study and hypotheses. Methodology is presented in section six. Section seven deals with results and discussion and findings are presented in section eight. Section nine deals with suggestion and section ten concludes.

\subsection{Stock market development and Economic Growth}

\section{Review of Literature}

As (K.Filer and et al, 1999) put, "one of the most enduring debates in economics is whether financial development causes economic growth or whether it is a consequence of increased economic activity. Using data for 64 countries for the years 1985-to-1997, Stock market activity (Velocity) as a proxy for stock market development and GDP as proxy for economic growth, they found a positive and significant causal relationship going from stock market activity to economic growth, particularly for less developed countries. Based on the data for 17 emerging market and 10 developed market economies during the period, from $2000-2011$, (Abiy Hailemariam and Chi Guotai, 2014)[13] using the generalized method of momentum (GMM) for dynamic panel data revealed that there exists statistically significant relationship between stock market development and economic growth both directly, as well as indirectly by boosting investment behavior. The results also indicated robustly that stock market development is an important wheel for economic growth.

Atje and Jovanovich (1989) made comparison on the extent of the impact that stock market development has on economic growth and bank development on subsequent economic growth. They found a large effect of stock market development as measured by the value traded divided by GDP on economic growth. Bekaert and Harvey (1997) also computed the rank correlations between six stock market development indicators and growth of real GDP in eighteen countries during the 1986-92 periods and the result confirmed that the stock market development positively impact economic growth.Equity (stock) markets are claimed to play fundamental roles in the growth of economies of both developed and developing countries. They serve as an avenue for entrepreneurs and young firms to raise long term fund. As a result, many scholars in the area of finance and economics have emphasized on examining the impacts of stock markets developments on economic growth.Literatures argue that stock markets accelerate economic growth by providing a boost to domestic savings and increasing the quantity and the quality of investment.

P. Wachtel, and P.L. Rousseau (2000)[14] asserts that 'Stock markets can promote economic performance by providing an exit mechanism to venture capitalists, offering liquidity to investors that encourages international diversification and portfolio flows, providing firms with access to permanent capital which can then be placed in large, indivisible projects, and generating information about the quality of potential investments'.Ngare and et al (2014) on their study, using annual data from a panel of 36 African countries, of which 18 had stock market over the period 1996-2010 confirmed that Countries with stock markets tend to grow faster compared to countries without stock markets and stock market development has a positive effect on economic growth. For the less developed countries, (K. Filer and et al, 1999) provided an empirical evidence of a positive and significant causal relationship between stock market development and economic growth, being the causality run from stock market development to economic growth.

\section{Need/Importance of the Study}

All the studies reviewed have emphasized on one or combination of the followings:

- What determines economic growth, proxied by growth in GDP;

- What determines the development of stock market, proxied by market capitalization as a percentage of GDP and/or turnover ratio, and;

- The causal linkage between stock market development and economic growth

This study attempts to examine whether there is significant difference between average GDP growth rate of countries with stock exchange and countries without stock exchange in SSA so that able to possibly prescribe establishment of stock exchange to speed up economic growth if there is significant difference especially for those countries like Ethiopia, one of the world fastest growing economy and the second populous in Africa, which do not have stock markets yet.

\section{Statement of the problem}

There are two contradicting views of the impact of Stock market in economic growth. The first view suggests developing countries to attempt for fostering bank-based financial system than to establish and encourage stock markets (Singh, 1993) [15]. The other view, which seems a wining view, prescribes low income countries to establish stock exchanges to enhance mobilization of fund from external sources for investment, which many African countries are short of, and allocation of the fund towards productive projects thereby enhancing economic growth.Ethiopia is one of African countries which do not have stock exchange yet 
and if it should opt for establishment of stock exchange, it will be customary to bench mark African peers which have stock exchanges and theoretically expected to register significant economic growth mainly due to stock exchange of their own or a regional stock exchange to which they are member.This study endeavors to find out whether there is significant difference in economic growth, using average GDP growth as proxy and over all macroeconomic performance difference between SSA countries without stock exchanges and countries with stock exchanges, which may motivate others to follow their footsteps.

\section{Objectives}

This study has two basic objectives:

- Examining whether there is meaningful macroeconomic performance difference between SSA countries which have stock exchanges in one group and countries that do not have in the other group for the years 1997-to-2013.

- Testing if there is significant difference on average GDP growth in the above two groups of countries for the same period and whether stock market development indicators explain variation in the rate of GDP growth for 17 African countries that have their own stock exchanges.

\subsection{Hypotheses}

The followings are the null hypotheses that this study tests:

$\mathrm{H}_{0}$ : there is no significant difference on GDP growth between SSA countries with stock exchanges and countries without stock exchanges

$\mathrm{H}_{01:}$ Stock exchanges did not significantly impacted GDP growth of African countries

\section{Methodology}

A Multi criteria decision making method helps to measure and rank the performance of a finite set of alternatives in terms of a number of decision criteria- decision criteria in this context are the three macroeconomic goals. The assumption in multi-criteria decision making is that the decision maker is capable of forecasting the performance of each alternative in terms of each one of the decision criteria. In this study, the numerical values for proxies of the three goals have been reported for the years 1997-to-2013 covered in the study. For this study, Sub Saharan African countries where Ethiopia is belong to are considered to be a policy alternative for a given country to benchmark and implement a macroeconomic policy of a country that performed relatively well as compared to peers in the region. The major question that should be addressed is how to rank the alternatives when all the decision criteria are considered simultaneously.

There are a number of MCDM models that are used to compute numerical values to determine a ranking of each alternative. Most widely used ones are the weighted sum Model (WSM), Weighted Product Model (WPM), Analytical hierarchy Process (AHP), Elimination and Choice Translating Reality ( ELECTRE) method and Technique for Order Preference by Similarity Ideal Solution (TOPSIS) method. In all these methods, the relative weights of importance of the criteria are subjective and computed using pair wise comparisons and the relatively best alternative is chosen through pair wise comparison of alternatives.If $\mathrm{n}$ is the number of criteria or alternatives, the number of all possible pair wise comparisons is equal to: (Triantaphyllou, 2000)[16]

$$
\text { n (n-1)/2 }
$$

This study covers 17 years period for 48 countries. The number of alternatives for a given country that may benchmark and imitate the macroeconomic policy equals the number of countries considered in the study. The number of possible comparisons in a single years equals $48(48-1) / 2=1,128$ which becomes very impractical. For this reason, a MCDM criteria method, TOPSIS is used in this study and Entropy method developed by (SHANNON, 1948) [17] has been applied to compute objective weights of the criteria.

TOPSIS (for the Technique for Order Preference by Similarity to Ideal Solution) was developed by Hwang and Yoon (1981) [18].

In this study, four macroeconomic variables are used to measure macroeconomic performance of African countries.

The macroeconomic performance function $\left(\mathrm{P}_{\mathrm{i})}\right.$ of a given country for the period $(\mathrm{t})$ may be written as

$$
P_{i t}=f\left(g_{i t}, P_{i t}, U_{i t}, I_{i t}\right)---(3-1)
$$

Where;

$\mathbf{P}_{\mathrm{it}}=$ macroeconomic performance of country (i) at period (t)

$\mathbf{g}_{\mathrm{it}}=$ the growth rate of real GDP,

$\mathbf{P G}_{\mathrm{it}}=$ the growth of real per capita GDP,

$\mathbf{U}_{\text {it }}=$ unemployment rate

$\mathbf{I}_{\text {it }}=$ the rate of inflation, and

In the above performance function, (g, and PG) are considered as "benefit attributes" for they impact macroeconomic performance positively - countries work towards increasing these variables and (u, I) are "cost 
attributes" for they impact macroeconomic performance negatively-countries always strive to reduce the figures in relation with these variables. Any country strives to formulate an economic policy that maximizes the benefit attributes and minimizes the cost attributes in order to build a well performing economy.

The countries performance with respect to each variable can be represented as a matrix (X) for $\mathbf{m}$ countries and four macroeconomic variables as:

$X(i)=\left\{X_{i 1}, X_{i}, X_{i 3}, X_{i 4}\right\}, X_{i j}$ being the value of the $i^{\text {th }}$ country with respect to $j^{\text {th }}$ macroeconomic variable in any particular year.

Where $\mathrm{j}=(\mathrm{g}, \mathrm{PG}, \mathrm{U}, \mathrm{I})$

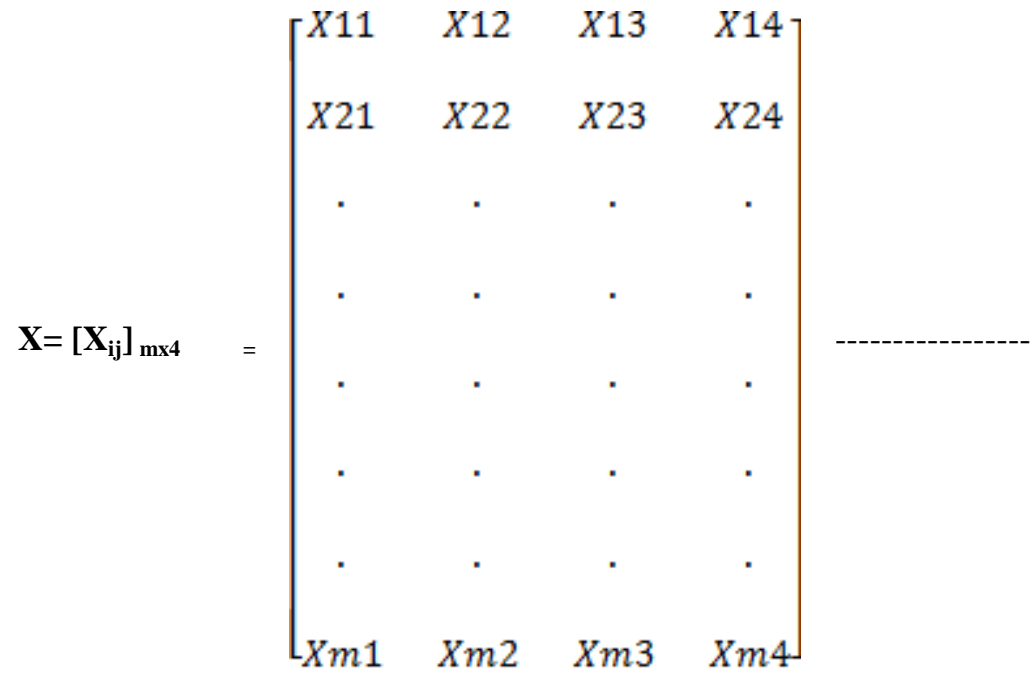

Applying TOPSIS technique of MCDM to the matrix, the overall macroeconomic performance of each country, which is explained by the relative position (rank), compared to others, in a particular year is computed. There are two extreme scenarios with respect to the possible performance outcomes of countries. The first scenario is the possibility that a country performs in absolute perfection in all of the variables or attributes. The other scenario is the possibility that a country may perform poorly in all attributes. In reality however, countries may perform well in one or more of the attributes and badly or unsatisfactorily in some of them.

The possible values for the performance levels in the above scenarios are termed as positive ideal solution and negative ideal solution for the scenarios one and two respectively. The relative performance of each country is judged by its proximity to these ideal solutions: how far it is from negative ideal solution and how closer it is to the positive ideal solution.

The TOPSIS method follows a number of steps so that relatively best alternatives (best performing countries in this context) can be found. For the criteria are usually expressed in different unit of measurement, first the various criteria are converted to non-dimensional criteria through normalization. (Triantaphyllou, 2000)

An element $\mathbf{r}_{\mathrm{ij}}$ of the normalized decision matrix $\mathrm{R}$ is thus calculated as follows:

$$
\mathrm{r}_{i j}=\frac{x_{i j}}{\sqrt{\sum_{k=1}^{m} X_{k j}^{2}}}
$$

A set of weights $\mathrm{W}=\left(\mathrm{W}_{1}, \mathrm{~W}_{2}, \mathrm{~W}_{3}, \quad \ldots, \mathrm{W}_{\mathrm{n}}\right)$, (where: $\left.\sum W i=1\right)$ defined by the decision maker is next used with the decision matrix to generate the weighted normalized matrix $\mathbf{V}$ as follows: 


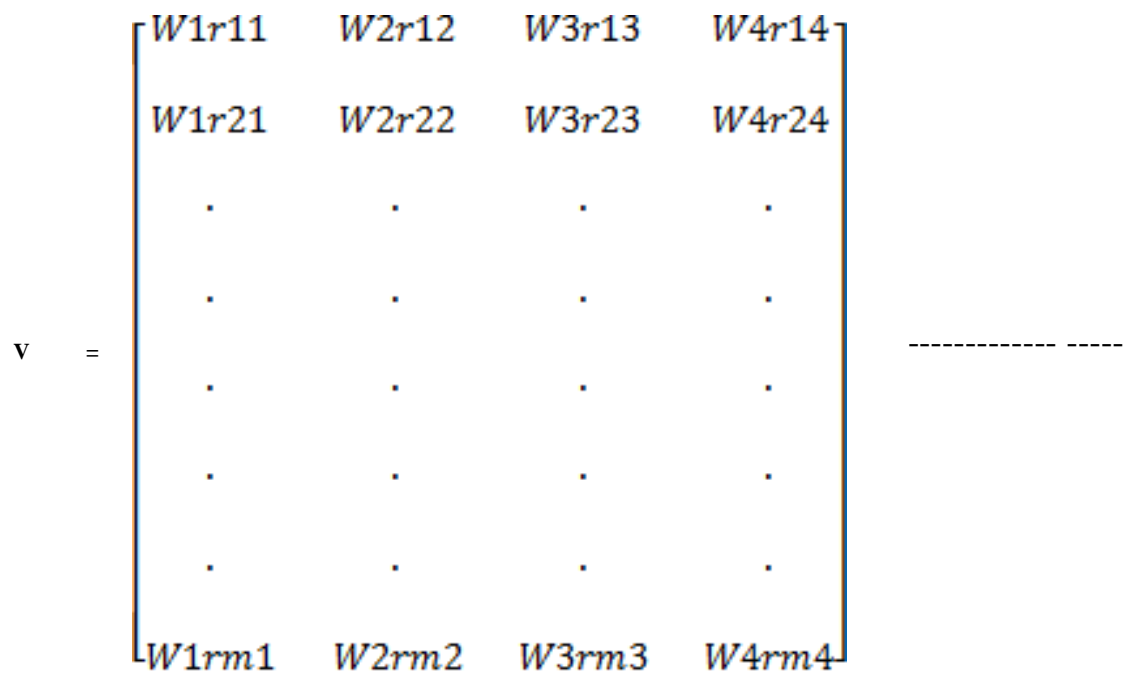

The ideal, denoted as $\mathrm{A}^{*}$, and the negative-ideal, denoted as A-, alternatives (solutions) are defined as follows:

$$
\begin{aligned}
A^{*}= & \left\{\left(\max _{\mathrm{i}} \mathrm{V}_{\mathrm{ij}} \mid \mathrm{j} \in \mathrm{J}\right),\left(\min _{\mathrm{i}} \mathrm{V}_{\mathrm{ij}} \mid \mathrm{j} \in \mathrm{J}^{\prime}\right), \mathrm{i}=1,2,3, \ldots, \mathrm{m}\right\} \\
= & \left\{\mathrm{v}_{1^{*}, \mathrm{v}_{2^{*}}, \mathrm{v}^{*},}, \mathrm{v}^{*}\right\} \\
\mathrm{A}^{-} & =\left\{\left(\min _{\mathrm{i}} \mathrm{V}_{\mathrm{ij}} \mid \mathrm{j} \in \mathrm{J}\right),\left(\max _{\mathrm{i}} \mathrm{V}_{\mathrm{ij}} \mid \mathrm{j} \in \mathrm{J}^{\prime}\right), \mathrm{i}=1,2,3, \mathrm{~m}\right\} \\
& =\left\{\mathrm{v}_{1-}, \mathrm{v}_{2-}, \mathrm{v}_{3-}, \mathrm{v}_{4}\right\}
\end{aligned}
$$

Where: $J=\{j=1,2,3 \ldots n$ and $j$ is associated with benefit criteria $\}$

$J^{\prime}=\{j=1,2,3 \ldots n$ and $j$ is associated with cost/loss criteria $\}$

The n-dimensional Euclidean distance method is next applied to measure the separation distances of each alternative from the ideal solution and negative-ideal solution.

$S_{i} *=\sqrt{\sum_{i=1}^{n}\left(V_{i j}-V_{j} *\right)^{2}}$ for $i=1,2,3 \ldots m$,

Where $\mathrm{Si}^{*}$ is the distance of each alternative from the ideal solution.

Similarly, for the distances from the negative-ideal solution we have:

$S_{i}-=\sqrt{\sum_{i=1}^{n}\left(V_{i j}-V_{j}-\right)^{2}}$ for $i=1,2,3 \ldots m$,

Where $\mathbf{S i}^{-}=$is the distance of each alternative from the negative-ideal solution.

The relative closeness of an alternative $\mathrm{Ai}$ with respect to the ideal solution $\mathrm{A}^{*}$ is defined as follows:

$C_{i}=\frac{s_{i}^{-}}{s_{i^{*}}+s_{i^{-}}}$Where $1 \geq C i * \geq 0$, and $i=1,2,3 \ldots m$

Countries now can be ranked according to their proximity to the ideal solution.

\section{Criteria's weight determination}

Each criterion has different level of bearing in the decision making or comparison process of alternatives at hand and hence different weight. As a result, it is important to find appropriate weights for each criterion.There are two methods of computing weights for criteria: subjective and objective weights (Lofti and Fallahnejad, 2010) [19]. While subjective weights are determined only according to the judgment of decision makers, the objective methods determine weights mathematically without considerations of the decision makers' judgment.The decision makers' expertise and judgment are considered when it is possible for the decision makers to attach logically acceptable subjective weights to each criterion. If attaching such subjective weight is difficult or at times impossible, it will be appropriate to use objective weight. In this study, for it is impossible to know how much weight is attached to each criterion by governments of each country as part of their macroeconomic policy, Shannon entropy concept (SHANNON, 1948), to determine objective weight is applied. There are steps to be followed:

S1: Normalize the decision matrix

Set $p_{i j}=\frac{x_{i j}}{\sum_{j=1}^{m} x_{i j}}, \mathrm{j}=1 \ldots m$

This process transforms different scales and units among various criteria into common measurable units to allow for comparisons of different criteria. 
S2: Compute entropy $h_{i}$ as, $h_{i}=-h_{0} \sum_{i=1}^{m}\left(p_{i j}, \ln p_{i j}\right), i=1, \ldots, n$

Where $h_{0}$ is the entropy constant and is equal to $(\ln m)^{-1}$ and

$P_{i j}$. $\ln P_{i j}$ is defined as 0 if $P_{i j}=0$.

S3: Set di $=1-h_{i}, \quad i=1 \ldots n$ as the degree of diversification of $i$.

S4: Set $\boldsymbol{w}_{i}=\frac{d i}{\sum_{s=1}^{\mathrm{n}} d s}, i=1 \ldots n$ as the degree of importance of attribute $I$------

\section{Data, Results And Discussion}

Data is obtained from the World Bank, World economic outlook \& World Development Indicators data bases and from annual reports of African Stock Exchanges Association (ASEA).From the 36 countries, that appeared at least once in the 17 years period in the 'top 20' best performing countries, ranked on the basis of macroeconomic performance measurement composite index, majority of the countries with stock exchange, be it their own or regional stock exchanges to which they are members, are in the list more frequently compared to countries without stock markets. During the 17 years period, 18 countries got listed in the top 20; from 10- to-17 times and all have stock exchanges. Of the total, it is only five countries that do not have stock exchanges. Their frequency however, is minimal compared to the majority of the countries having stock exchange.

Table 4.1. Top 20 performers

\begin{tabular}{|c|c|c|c|}
\hline & Country Name & $\begin{array}{l}\text { Frequencies of Appearance in the } \\
\text { ranking }\end{array}$ & Does a country has Stock Exchange (Yes/No) \\
\hline 1 & Mauritius & 17 & Yes \\
\hline 2 & Benin & 17 & Yes Regional stock exchange \\
\hline 3 & Cameroon & 17 & yes \\
\hline 4 & South Africa & 16 & Yes \\
\hline 5 & Botswana & 16 & Yes \\
\hline 6 & Equatorial Guinea & 15 & Yes Regional stock exchange \\
\hline 7 & Swaziland & 15 & Yes \\
\hline 8 & Cape Verde & 15 & Yes \\
\hline 9 & Nigeria & 13 & Yes \\
\hline 10 & Cote d'voire & 13 & Yes \\
\hline 11 & Gabon & 12 & Yes Regional stock exchange \\
\hline 12 & Rwanda & 12 & Yes \\
\hline 13 & Burkina Faso & 12 & Yes Regional stock exchange \\
\hline 14 & Tanzania & 12 & Yes \\
\hline 15 & Uganda & 12 & Yes \\
\hline 16 & Senegal & 11 & Yes Regional stock exchange \\
\hline 17 & Niger & 11 & Yes Regional stock exchange \\
\hline 18 & Mali & 10 & Yes Regional stock exchange \\
\hline 19 & Angola & 9 & No \\
\hline 20 & Ghana & 9 & Yes \\
\hline 21 & Ethiopia & 9 & No \\
\hline 22 & Togo & 8 & Yes Regional stock exchange \\
\hline 23 & Gambia & 7 & Yes Regional stock exchange \\
\hline 24 & Central African Rep. & 7 & Yes Regional stock exchange \\
\hline 25 & Chad & 6 & Yes Regional stock exchange \\
\hline 26 & Mozambique & 6 & Yes \\
\hline 27 & Sudan & 5 & Yes \\
\hline 28 & Guinea-Bissau & 5 & Yes Regional stock exchange \\
\hline 29 & Madagascar & 5 & No \\
\hline 30 & Congo Dem.Rep & 4 & Yes Regional stock exchange \\
\hline 31 & Zimbabwe & 4 & Yes \\
\hline 32 & Kenya & 3 & Yes \\
\hline 33 & Mauritania & 3 & No \\
\hline 34 & Sierra Leone & 3 & Yes \\
\hline 35 & Burundi & 1 & No \\
\hline 36 & Malawi & 1 & Yes \\
\hline
\end{tabular}

Source: Own computation

This gives even more meaning if the top ten only are considered. Of the 24 countries in this list, only one does not have stock exchange- Angola. Angola's performance can probably be attributed to its oil production. The economy of Angola has been reported ${ }^{1}$ as it is largely dependent on oil and oil production accounts for $40 \%$ Angola's GDP.

${ }^{1}$ http://www.africanvault.com/oil-producing-countries-in-africa/ , Accessed on January 19, 2017

DOI: 10.9790/5933-0801030111 www.iosrjournals.org 
Table 4.2. Top 10 performers

\begin{tabular}{|l|l|l|}
\hline & Country Name & Frequency \\
\hline 1 & Equatorial Guinea & 15 \\
\hline 2 & Gabon & 12 \\
\hline 3 & Mauritius & 17 \\
\hline 4 & South Africa & 16 \\
\hline 5 & Botswana & 16 \\
\hline 6 & Angola & 9 \\
\hline 7 & Swaziland & 7 \\
\hline 8 & Cape Verde & 15 \\
\hline 9 & Nigeria & 5 \\
\hline 10 & Mali & 3 \\
\hline 11 & Togo & 1 \\
\hline 12 & Rwanda & 5 \\
\hline 13 & Cote d'voire & 7 \\
\hline 14 & Senegal & 5 \\
\hline 15 & Benin & 11 \\
\hline 16 & Cameroon & 12 \\
\hline 17 & Chad & 2 \\
\hline 18 & Niger & 1 \\
\hline 19 & Burkina Faso & 5 \\
\hline 20 & Tanzania & 2 \\
\hline 21 & Uganda & 1 \\
\hline 22 & Sudan & 1 \\
\hline 23 & Mozambique & 1 \\
\hline 24 & Congo Dem.Rep & 1 \\
\hline & & $c 0 m p t a t i o n$ \\
\hline
\end{tabular}

Source: Own computation

From the preceding, it seems countries with stock exchanges do have better macroeconomic performance than countries without stock exchange. However, the fact that countries with stock exchanges get listed in the rank with less frequency compared to some of the countries which do not have stock exchanges, tells having a stock exchange is not a sufficient condition for a country to exhibit a better macroeconomic performance.Growth rate of real GDP is one of the factors used in the computation of macroeconomic performance measurement composite index and for there are a number of studies conducted in Africa and elsewhere that assert stock exchange promote growth, an effort has been made in this study to look into whether there is significant difference in the average GDP growth rate of Sub Saharan African countries with stock exchanges and countries without stock exchange using an independent T-test. The normality test and T-test for the periods 1997-to-2013 and 2004-to-2013 are presented below. Ranking of countries on the basis of macroeconomic performance has been done for the period 1997-to-2013 and for this reason, a separate test is done and the years from 2004-to-2013 is chosen just to see if there is any difference for the recent past as a function of expected development of their stock exchange through time.

\section{Normality-test}

Normality can be tested using skewness and kurtosis by converting the scores to Z-scores by dividing by their standard error: (Field, 2009)[20]

\begin{tabular}{|c|c|}
\hline$Z_{\text {skewness }}=S / S E_{\text {skewness }}$ & $Z_{\text {skewness }}=.332 / .354=0.94<1.96$ \\
\hline $\mathrm{Z}_{\text {Kurtosos }}=\mathrm{K} / \mathrm{SE}$ Kurtosos & $Z_{\text {Kurtosos }}=.198 / .695=0.28<1.96$ \\
\hline
\end{tabular}

Since the resulting score in each are less than $1.96(\mathrm{P}>.05)$, the scores are not significant and the distribution is normal. The shapiro-Wilk test also confirms the normality. 


\begin{tabular}{|c|c|c|c|c|}
\hline \multicolumn{5}{|c|}{ Descriptives } \\
\hline & & & Statiatic & Std. Error \\
\hline \multirow{13}{*}{$\begin{array}{l}\text { GDP growth Moving Average } \\
\text { (17 years) }\end{array}$} & Mean & & 4.2598 & .33634 \\
\hline & $95 \%$ Confidence interval for & Lower Bound & 3.5819 & \\
\hline & Mean & Upper Bound & 4.9378 & \\
\hline & $5 \%$ Trimmed Mean & & 4.3420 & \\
\hline & Median & & 4.0779 & \\
\hline & Variance & & 5.091 & \\
\hline & Std. Deviation & & 2.25624 & \\
\hline & Minimum & & -1.59 & \\
\hline & Maximum & & 8.18 & \\
\hline & Range & & 9.77 & \\
\hline & Interquartile Range & & 3.12 & \\
\hline & Skewness & & -.332 & .354 \\
\hline & Kurtosis & & 198 & .695 \\
\hline
\end{tabular}

\begin{tabular}{|l|r|r|r|r|r|r|}
\hline & \multicolumn{3}{|c|}{ Kolmogorov-Smirnov } & \multicolumn{3}{c|}{ Shapiro-Wilk } \\
\cline { 2 - 7 } & Statistic & \multicolumn{1}{c|}{ df } & Sig. & Statistic & \multicolumn{1}{c|}{ df } & \multicolumn{1}{c|}{ Sig. } \\
\hline $\begin{array}{l}\text { GDP growth Moving Average } \\
\text { (17 years) }\end{array}$ & .096 & 45 & .200 & .969 & 45 & .272 \\
\hline
\end{tabular}

a. Lilliefors Significance Correction

*. This is a lower bound of the true significance.

\section{T-Test}

Since Levene's test is insignificant $(\mathrm{P}>.05)$, there is no sufficient evidence to reject the null hypothesis that the difference between the variances of means of the average GDP growth rate of countries with stock exchange and countries without stock exchange is zero.

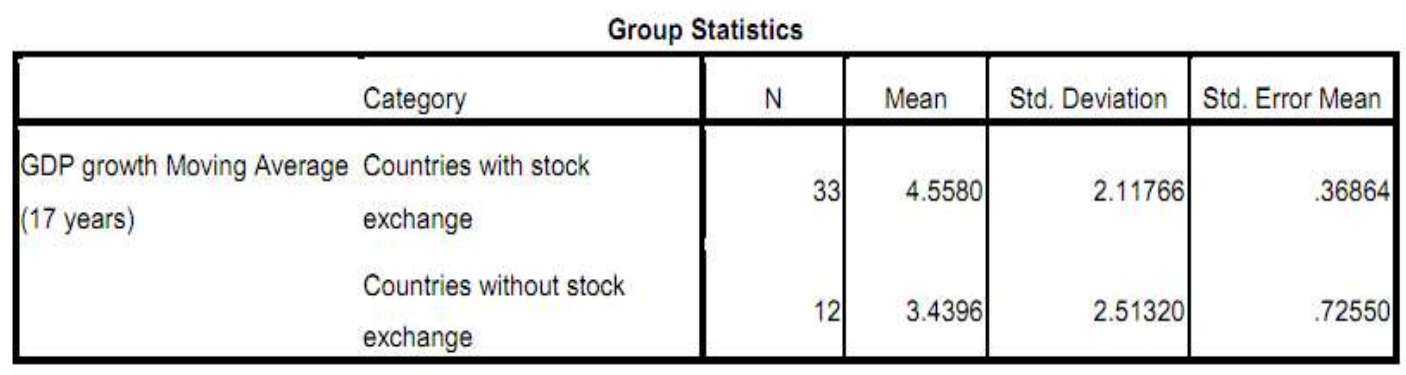

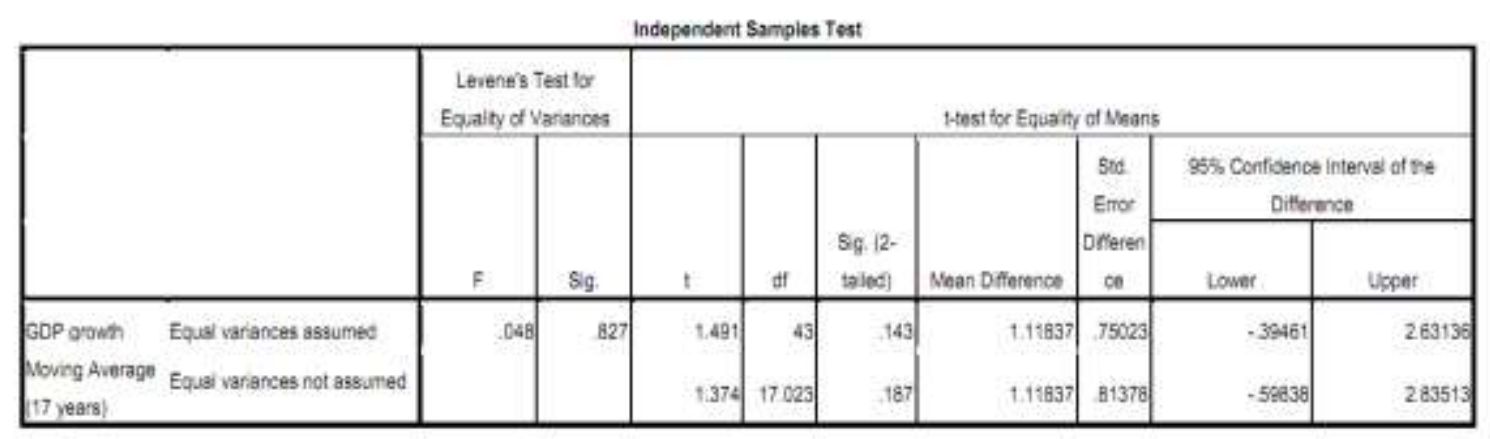

The result of the T-test tells that there is no significant average GDP growth difference between countries with stock exchange and countries without stock exchange in sub-Saharan Africa during the period 1997-to-2013. 
Since the result of the T-test for the 17 years period is against the expected result, same test has been made for the years 2004-2013. Same procedures followed for the 17 years period, have confirmed that the distribution for the years 2004-to-2013 is normal.

\begin{tabular}{|c|c|c|c|c|}
\hline & & & Statiatic & Sta. Error \\
\hline GDP_orowth_Average & $\begin{array}{l}\text { Mean } \\
\text { 9s\% Canfidence Interval for } \\
\text { Mean } \\
5 \% \text { Trimmed Mwan } \\
\text { Median } \\
\text { Variance } \\
\text { Std. Deviation } \\
\text { Minimum } \\
\text { Maximum } \\
\text { Range } \\
\text { Interquartile Range } \\
\text { Skewness } \\
\text { Kurtosis }\end{array}$ & $\begin{array}{l}\text { Lower Bound } \\
\text { Upper Bound }\end{array}$ & $\begin{array}{r}5.0097 \\
4.2038 \\
5.8166 \\
5.0408 \\
5.0184 \\
7.533 \\
2.74464 \\
-2.71 \\
11.02 \\
13.73 \\
3.66 \\
-119 \\
.769\end{array}$ & .347 \\
\hline
\end{tabular}

\begin{tabular}{|l|r|r|r|r|r|r|}
\hline \multirow{2}{*}{} & \multicolumn{3}{|c|}{ Kosts of Normality } & \multicolumn{3}{c|}{ Shapiro-Wilk } \\
\cline { 2 - 7 } & Statistic & df & sig & Statigtic & df & sig. \\
\hline GDP_growth_Average & Sig & 47 & .200 & 979 & 47 & 561 \\
\hline
\end{tabular}

a. Lilliefors Significance Correction

*. This is a lower bound of the true significance.

Similar result of T-test that shows there was no significant difference in average GDP growth between countries with stock exchange and without, is obtained for the years 2004-to-2013.

\begin{tabular}{|c|c|c|c|c|c|}
\hline \multicolumn{6}{|c|}{ Group Statiefies } \\
\hline & Group & N & Moan & Syt Denviation & Sxy. Emor Manse \\
\hline ODe_growh_Aursage & $\begin{array}{l}\text { courtries w th sicok } \\
\text { exchengs } \\
\text { cointries w theut stock } \\
\text { exchangs }\end{array}$ & 18 & $\begin{array}{l}5.77 \pi \\
4.5702\end{array}$ & $\begin{array}{l}232270 \\
375023\end{array}$ & $\begin{array}{r}39834 \\
1.02848\end{array}$ \\
\hline
\end{tabular}

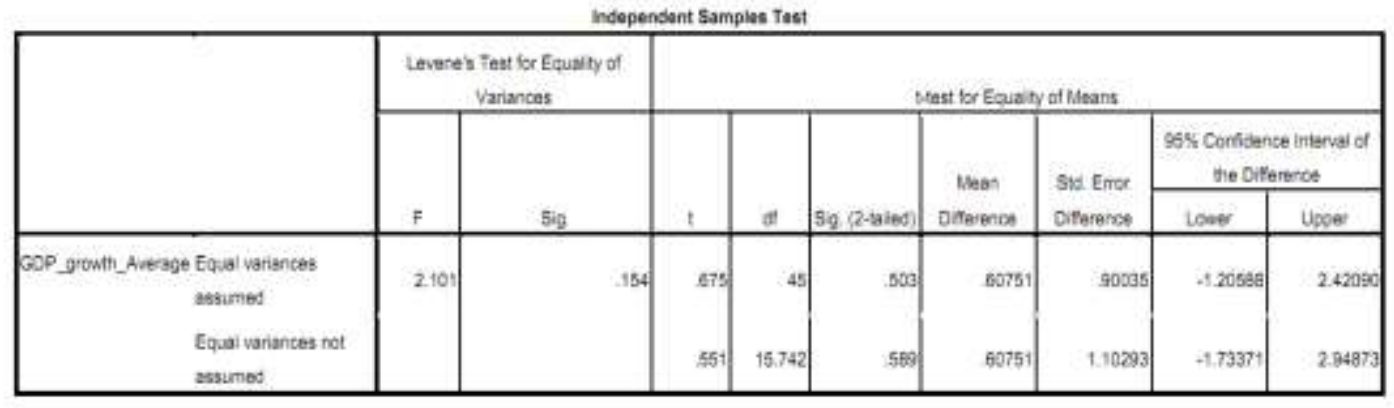

The fact that there is no significant difference between the average GDP growth rate of countries with stock exchanges and countries without stock exchanges does not mean that stock exchanges in SSA do not promote growth.Panel regression has been run using panel data for 18 African countries those have their own stock exchanges for the years 2003to-2014. This period is chosen due to the availability of data. As the regression outputs show, the random-effect regression model is fit and the Hausman test also confirms the random effect model is appropriate. The regression was run with the intent of examining whether the stock market development indicators significantly impact the rate of growth of GDP in these African countries. The regression output tells that both indicators of stock market development are positively correlated. However, while the rate of stock market capitalization as a percentage of GDP significantly and positively impacts the rate of GDP growth, turnover ratio is not.

Fixed-effects (within) regression

R-sq: within $=0.0172$

Between $=0.3515$

Overall $=0.0776$ 
Prob $>\mathrm{F}=0.3985$

\begin{tabular}{|c|c|c|c|c|c|c|}
\hline $\log G D P$ & Coef. & Std. Err. & t & $\mathrm{P}>|\mathrm{t}|$ & [95: Conf. & Interval] \\
\hline $\begin{array}{r}\text { logTurnover } \\
\text { logmrktcap } \\
\text { cons }\end{array}$ & $\begin{array}{l}.0198504 \\
.0628406 \\
.5543457\end{array}$ & $\begin{array}{r}.0323188 \\
.0586283 \\
.088094\end{array}$ & $\begin{array}{l}0.61 \\
1.07 \\
6.29\end{array}$ & $\begin{array}{l}0.540 \\
0.286 \\
0.000\end{array}$ & $\begin{array}{r}-.0442248 \\
-.0533957 \\
.3796908\end{array}$ & $\begin{array}{l}.0839256 \\
.1790769 \\
.7290005\end{array}$ \\
\hline $\begin{array}{c}\text { sigma_u } \\
\text { sigma_e } \\
\text { rho }\end{array}$ & $\begin{array}{l}.10831946 \\
.23507557 \\
.17513763\end{array}$ & (fraction & & ce due & U_i) & \\
\hline
\end{tabular}

Random-effects GLS regression

R-sq: within $=0.0171$

Between $=0.3476$

Overall $=0.0782$

\begin{tabular}{|c|c|c|c|c|c|c|}
\hline $\log G D P$ & Coef. & Std. Err. & $z$ & $\mathrm{P}>|z|$ & [95\% Conf. & Interval] \\
\hline $\begin{array}{r}\text { logTurnover } \\
\text { logmrktcap } \\
\text { cons }\end{array}$ & $\begin{array}{r}.0185259 \\
.074633 \\
.5398311\end{array}$ & $\begin{array}{l}.0273182 \\
.0300444 \\
.0481139\end{array}$ & $\begin{array}{r}0.68 \\
2.48 \\
11.22\end{array}$ & $\begin{array}{l}0.498 \\
0.013 \\
0.000\end{array}$ & $\begin{array}{r}-.0350168 \\
.0157471 \\
.4455296\end{array}$ & $\begin{array}{r}.0720685 \\
.133519 \\
.6341326\end{array}$ \\
\hline $\begin{array}{r}\text { sigma_u } \\
\text { sigma_e } \\
\text { rho }\end{array}$ & $\begin{array}{l}.05377741 \\
.23507557 \\
.04973146\end{array}$ & (fraction & var & ce due & u_i) & \\
\hline
\end{tabular}

- hausman fe re

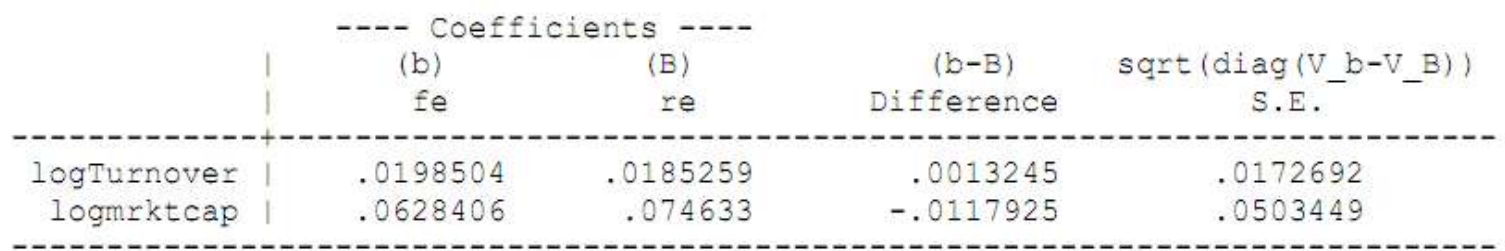

$\mathrm{b}=$ consistent under Ho and Ha; obtained from xtreg

$B=$ inconsistent under Ha, efficient under Ho; obtained from xtreg

Test: Ho: difference in coefficients not systematic

$$
\begin{aligned}
& \operatorname{chi2}(2)=(b-B) \cdot\left[\left(V_{-} b_{-}-V_{-} B\right) \wedge(-1)\right](b-B) \\
& =0 . \overline{0} 6 \\
& \text { Prob>chi2 = } 0.9714
\end{aligned}
$$

* Since probability of $\mathbf{C h i}^{2}$ is $>.05$, we accept the null and conclude the Random effect estimator is appropriate.

Therefore, from the panel data regression and the T-test, it is possible to safely conclude that establishment of stock exchange promotes GDP growth but the impact is not as such significant to the extent that brings considerable difference in GDP growth between those African countries with stock exchanges and those do not have stock exchanges. This result is in agreement with results of previous studies by Ngare and et al (2014), P Wactel and P.L.Rousseau, K.Filer and et al (1999) Carporale and et al (2004), Atje and Jovanovich (1989), Abiy Hailemariam and Chi Guotai (2014), Al-Quda ( 2014), IShiro, O. (2013) [21], Nazir and et al (2010)[22] Hossain and et al (2013)[23] to mention some. However, for the stock exchanges to cause economic growth and for the impact to be visible, the market should be liquid and highly active as Baubakari and Jin (2010) assert. This may be the major reason why there is no significant difference between the average GDP growth rate of countries with stock exchanges and countries without stock exchanges in Africa, which this study finds, 
for the African stock exchanges are generally characterized as illiquid and turnover ratio, which is a better indicator for liquidity is not significant in the above panel data regression output of this study.

\section{Findings}

The study finds that SSA countries that have stock exchanges have exhibited a better macroeconomic performance compared to those SSA countries which do not have stock exchanges that is explained by the frequency of appearance in the macroeconomic performance ranking. However, the independent sample T-test that was done to see if there was any significant difference on GDP growth and attributable to difference on macroeconomic performance, considering GDP as major goal that macroeconomic policy emphasizes on, significant difference was not observed in the GDP growth rate in these two groups of SSA countries. From the result of panel data regression analysis, the random effect regression is found to be appropriate after Hausman test. Market capitalization as a percentage of GDP is found to impact the rate of GDP growth significantly and positively. Turnover ratio impacted the rate of GDP growth positively but it was not significant.

\section{Recommendations/Suggestions}

The winning view about the impact of stock market on economic growth is that stock market enhances economic growth. However, for African countries in order to reap the potential benefits that stock markets offer, the markets need to have adequate supply of shares and balanced demand for them. One of the possible reasons for insignificant impact of turnover ratio on GDP growth may be because majority of African stock exchanges except Johannesburg stock exchange are characterized as illiquid and thin. Therefore, governments may introduce policy incentives which may encourage domestic companies from different sectors of the economy may go public and open up their markets to foreign participation to increase the demand side and also allow investors to diversify risk.

\section{Conclusion}

This study concludes that stock markets impact economic growth in Africa positively but the difference in GDP growth between those countries which have stock exchanges and those do not have is not significant. However, countries with stock exchanges performed well on the overall macroeconomic performance and the difference is meaningful in this regard.

\section{Bibliography}

[1]. Wamburu, K. K. \& Wainaina,G., 2014. "Determinants Of Stock Marketdevelopment In Kenya: An Error Correction Modelapproach". European Journal Of Business Management, 1(11), Pp. 1-14.

[2]. Bekaert And Harvey. (1997, May)." Capital Markets: An Engine For Economic Growth".

[3]. Carporale And Et Al. (2004). "Stock Market Development And Economic Growth: The Causal Linkage". Journal Of Economic Development, 29(1).

[4]. Atje R., And Jovanovic B. (1989). "Stock Markets And Development." European Economic Review, 37, 632-640.

[5]. K. Filer And Et Al. (1999, September ). "Do Stock Markets Promote Growth?", Working Paper Number 267, 1-25.

[6]. Al-Qudah. (2014). "Stock Exchange Development And Economic Growth: Empirical Evidence From Jordan." International Journal Of Business And Management, 9(11).

[7]. $\quad$ Ngare And Et Al. (2014)." Stock Market Development And Economic Growth In Africa." Journal Of Economics And Business, 74, 24-39.

[8]. O. Olweny And Kimani, 2011. "Stock Market Performance And Economic Growth Empirical Evidence From Kenya Using Causalitytest Approach". Advances In Management \& Applied Economics, 1(3), Pp. 153-196.

[9]. Boubakari And Jin, 2010. The Role Of Stock Market Development In Economic Growth: Evidence From Some Euronext Countries. International Journal Of Financial Research, 1(1), Pp. 14-20.

[10]. Levine, R., 1996. "Stock Markets:A Spur To Economic Growth". Finance \& Development, Pp. 7-10.

[11]. Musonera And Safari, 2008. "Establishing A Stock Exchange In Emerging Economies And Opportunities". The Journal Of International Management Studies, 3(2), Pp. 62-68.

[12]. Welsch, 2011. "The Magic Triangle Of Macroeconomics:How Do European Countries Score?". Oxford Economic Papers, Volume 63, P. 71-93.

[13]. Abiy Hailemariam And Chi Guotai, 2014. Stock Market Development And Economic Growth: Empirical Evidence For Emerging Market Economies. International Journal Of Economics, Finance And Management Sciences, 2(2), Pp. 171-181.

[14]. P. Wachtel, And P.L. Rousseau, 2000. "Equity Markets And Growth: Cross-Country Evidence On Timing And Outcomes, 19801995". Journal Of Banking \& Finance, Volume 24, Pp. 1933-1957.

[15]. Singh, 1993. "The Stock -Market And Economic Development: Should Developing Countries Encourage Stock-Markets?". Unctad Review, Pp. 1-28.

[16]. Triantaphyllou, 2000. "Multi-Criteria Decision Making Methods: A Comparative Study." S.L.:Kluwer Academic Publishers.

[17]. Shannon, 1948. A Mathematical Theory Of Communication. The Bell System Technical Journal, Volume 27, P. 379-423.

[18]. Hwang C.L., Yoon K. (1981): Multiple Attribute Decision Making: Methods And Applications. Springer-Verlag, Berlin.

[19]. Lofti And Fallahnejad, 2010. "Imprecise Shannon's Entropy And Multi Attribute Decision Making". Entropy, Volume 12, Pp. 5362.

[20]. Field, A., 2009. Discovering Statistics Using Spss. Third Edition Ed. New Delhi: Sage Publications India Pvt Ltd.

[21]. Ishioro, O., 2013. "Stock Market Development And Economic Growth: Evidence From Zimbabwe", Ekon.. Ekon. Misao Praksa Dbk. God Xxii., Volume 2, Pp. 343-360.

[22]. Nazir And Et Al, 2010. "Relationship Between Economic Growth And Stock Market Development". African Journal Of Business Management, 4(16), Pp. 3473-3479.

[23]. Hossain And Et Al, 2013. "An Examination Of The Relationship Between Stock Market And Economic Growth: A Study In Malaysia". Journal Of Transformative Entrepreneurship, 1(2), Pp. 124-133. 